\title{
Hotels and Halal-oriented Products: What Do Hotel Managers in Slovenia Think?
}

\author{
Metod ŠULIGOJ', Helena MARUŠKO² \\ 1 University of Primorska, Faculty of Tourism Studies - Turistica, Obala 11a, 6320 Portorož/Portorose, Slovenia \\ metod.suligoj@fts.upr.si (corresponding author) \\ ${ }^{2}$ Independent consultant, Vurnikov trg 4, 4320 Radovljica, Slovenia
}

\begin{abstract}
Background and Purpose: Tourists from the Islamic world are significant stakeholders in the tourism market. The purpose of this paper is to identify the key aspects of halal tourism in connection with the hotel industry. Furthermore, we want to determine whether hotel managers are familiar with halal certification and on what basis they would opt for it.

Design/Methodology/Approach: The research focuses on halal goods, services, and facilities, in general, and specifically in Slovenian hotels; concepts, contemporary trends, and the situation in Slovenia are presented. In response to the literature review, we applied the analysis of the factor loadings to define the important factors that influence the decision-making process; by applying PCA, we reduced the dependent variable to a single factor (although predictions were slightly different).

Findings: The most important elements in the adoption of the certificate are the simplicity and efficiency of the procedure itself and the fact that the process does not require major financial investments. The element that significantly influences the managers' decision-making process is the possibility of adjusting to the standard of the certificate.

Conclusion: The paper's main contribution is to deepen the perspective of the development of tourism in an area that remains a relatively undeveloped and unknown niche within the Slovenian tourism/hospitality industry but very promising in the global context.
\end{abstract}

Keywords: hotel managers; halal certificate; Islam; thematic offer; Slovenia; Croatia

\section{Introduction}

Muslim tourists are significant stakeholders in the tourism market, although the Western world until recently has viewed them, for example, only as pilgrims to Mecca. Undoubtedly, in recent years there have been major shifts in the travel habits of the Muslim population. Muslim tourists are one of the fastest growing segments in the world, second only to Chinese tourists (Aladjem, 2012). They can be defined as guests who are just entering the global tourism market, with increased purchasing power and a strong desire to pursue their social status (Onislam.net, 2010), seeking a holiday in places where they can follow their religious principles and have access to services which are in accordance with their lifestyle (Aladjem, 2012).

According to recent research of Dinar Standard (2012) in 2011, Muslim tourists spend about 102 billion Euros on their travels. Moreover, they are characterised by a dominant share of young people, since nearly half of the world's Muslim population is younger than 24 years. By 2030, the global proportion of young Muslims will grow twice as fast as the share of young people in non-Muslim countries (Baker, 2011); considering the entire world Muslim population, which has 1.8 billion people, and is rapidly increasing and is expected to represent $30 \%$ of the world population by 2025 (Dinar Standard, 2012). Young people are educated, and eager to gain new knowledge and discover new places (Baker, 2011); more than 52.7\% of Muslim tourists

Received: March 10, 2017; revised: September 14, 2017; accepted: October 3, 2017 
travel for leisure and entertainment, with $50 \%$ of them preferring halal services, $30 \%$ would seek services that are fully consistent with sharia law (Dinar Standard, 2012). The data show that it is not a narrow market niche, but a significant trend that will have a strong impact on the global tourism sector in the coming years (Razalli, Yusoff \& Roslan, 2013). The specific needs of Muslim guests raised the demand for adjusted products and services, which are known as 'halal'. This is defined as a sub-category of religious tourism and includes airlines, travel agencies, tour operators and hotels (Henderson, 2010). The concept of halal appeared more frequently in connection with food, which is prepared in accordance with Islamic principles, ${ }^{1}$ but today it indicates a wide range of different products and services, e.g. financial operations, cosmetic products, vaccines, and last but not least tourism services (Piangpis, Oraphan \& Hamzah, 2014). Consequently, in recent years, many countries in the world have shown an incrementally increasing interest in the concept of halal tourism (Battour, Ismail \& Battor, 2011). Therefore, the primary purpose of this study is to present the fundamental aspects of halal tourism in connection to the hotel industry.

Since 1991,2 Slovenian tourism has developed and grown with above-average dynamics. It has contributed almost a $13 \%$ share of the GDP in recent years and employs approximately $13 \%$ of all employees in the country. It is very internationally oriented: the main sales markets are Italy, Austria, Germany, and Croatia. Around $60 \%$ of tourists use hotel accommodation, followed by campsites (Slovenian tourist board, 2017; Slovenian tourist board, n.d.). However, in Slovenian tourism, the topic of halal products and services is completely unexplored and was not included in the 2012-2016 Slovenian Tourism Development Strategy (The Government of the Republic of Slovenia, 2012) or The 2017-2021 Strategy for the Sustainable Growth of Slovenian Tourism (The Government of the Republic of Slovenia, 2017). For example, in February 2016, only five halal-certified hotels were operating. The fieldwork of this study was conducted in the fall of 2015 in order to determine the attitude of managers of hotels with at least three stars toward services for Muslim guests. Our search in COBISS (Co-operative Online Bibliographic System and Services), HRČAK (Portal of Scientific Journals of Croatia) and in large international bibliographic indexes such as Emerald, Elsevier, and the Taylor \& Francis Group indicates that no research of this kind has been published.

\section{Islam as the basis for the tourist engagement}

Islam is a religion that strongly encourages travel. Among Muslims, it is believed that they are closer to God when they travel and that their prayers during the journey are more effective (Timothy \& Olsen, 2006; Kovjanic, 2014). In Islam, historically speaking, there were many different types of travel with significant religious roles, which changed and adapted over time (Henderson, 2003). It is especially important to emphasise that the act of travelling in Islam is 'purposeful', with a strong emphasis on the religious impulses: to strengthen the relationship between the broader Muslim community or umma (Ummah, Ummet) and the continuation of the long history of Muslim travels (Henderson, 2003; Kovjanic, 2014); the Muslim religion is a way of life (Boisard, 2002) or life itself (Nasr, 2007). In compliance with sharia law, Muslims place a high value on the tourist experience and rely heavily on the ethical dimension and tradition, which is not always typical for the tourists from the Western world (Sureerat et al., 2015).

When Muslims decide on tourist destinations, they particularly pay attention to halal food ( $67 \%$ of them), the overall value ( $53 \%$ of them), and the experience being suitable for Muslims (49\% of them) (Baker, 2011); when they travel to distant places, they travel in groups, which is also encouraged by the Islamic tradition. Thus, the majority of Muslims around the world decide to travel in the company of family members and friends (Timothy \& Olsen, 2006, p. 199; Aladjem, 2012). Hence, their holiday calendar is designed differently than in other cultures/religions, where most people go on vacation during certain seasons or times of the year (Aladjem, 2012): Muslims are guided by the lunar calendar and follow the phases of the moon, and thus go on vacations in different periods of time and to different locations/destinations. Ramada month (Ramazan) with the feast of Eid al-Fitr (Bajram) and the feast of Eid al-Adha (Kurban Bairam) are the central events in the traditional holiday calendar when many Muslims choose to travel.

\section{Halal (tourism) and hotels}

Halal tourism is defined as a sub-category of religious tourism that includes airlines, travel agencies, tour operators, hotels (Henderson, 2010), food and beverage providers, logistics, finance, tourism packages, SPA centres (Zulkifli et al., 2011) and any other guest activities regarding the consumption of products and services adjusted to Islamic principles (Duman, 2011). Irrespective of the product classification, the main attributes of halal tourism are based on factors that satisfy the basic religious needs of Muslim guests: access to halal food, prayer facilities (Battour,

1 More can be found in Food and Agriculture Organization of the United Nations (FAO) (n.d.).

2 The year of the proclamation of the independence of Slovenia. 
Ismail \& Battor, 2001; Hashim, Murphy \& Muhammad, 2007), discrete dress code (Henderson, 2010), ban on the sale of alcoholic beverages, and the prohibition of gaming services (Din, 1989).

The hotel industry has established the concept of (a) the halal hotel that is fully operational in accordance with Islamic principles ${ }^{3}$ and (b) the halal-friendly hotel, which, in addition to its existing range of services, also offers services tailored to Islamic principles. The halal hotel is not restricted to supplying only halal food and drinks, since all hotel services/activities are carried out in accordance with Islamic principles (Sureerat et al., 2015). Henderson (2010) was the first to indicate the basic characteristics and attributes of halal hotels. Halal hotels attract mostly conscious guests who respect and appreciate the environment, culture, heritage, well-being, and the green character of the place (Al Bawaba, 2007), which could be more profitable than offering standard hotel services (Morgan, Pritchard \& Piggott, 2002). In any case, the halal certificate is a successful marketing tool for promoting halal trademarks or services (Rajagopal et al., 2011), giving the halal-certified hotel an added competitive advantage for attracting foreign and domestic guests (Zaliani, Omar \& Kopong, 2011), whether they are religious or not. ${ }^{4}$ The process for obtaining the halal certification has a favourable effect on the six dimensions of the performance of the hotel: the qualifications of the hotel staff, employee motivation, increased the range of skills of employees, better efficiency, environmental awareness, and economic wisdom (Razalli, Abdullah \& Yusoff, 2012). Obtaining the halal certification, in fact, depends on the adjustment of certain hotel processes, greater emphasis on quality control, and the training of hotel staff.

The global halal tourism market in 2013 reached a value of around 140 billion USD, which represents approximately $13 \%$ of the total world tourism industry and is $60 \%$ more than three years before (Crnjak, 2014); according to Rezidor Hotel Group it is estimated to increase by $20 \%$ in the next decade (Saad, 2013). In addition to its rapid growth halal tourism also brings guests who spend much more money, on average about 1,700 USD per day than Europeans, who spend on average 500 USD (Saad, 2013); Kovjanic, 2014, 36). The trend, of course, has been quickly detected by many tourism service providers who aligned to the needs of the new segment with the acquisition of halal certificates. In this context, two completely different examples are highlighted in the following sub-chapters.

\subsection{Halal concept in the Croatian hotel industry}

Croatia has already declared itself to be a halal-friendly destination and started an extensive campaign to promote their halal offerings, which resulted in high media coverage, e.g. Crnjak (2014), Šoštarić (2014), Latinović (2016). Croatia is also the first country in the European Union to have standardised the certification procedures and is also actively engaged on the international level in order to reach an agreement between countries on a uniform procedure of certification. In December 2014, Croatia had 12 certified accommodation facilities (Crnjak, 2014); the updated list is available on the website of the Centre for Halal Quality Certification of the Islamic Community in Croatia (http:// halal.hr/pruzatelji-usluga/). ${ }^{5}$ Experiences of some hotels in Zagreb, which already have the halal certificate, show that the halal certification is a good opportunity for the development of not just leisure tourism, but also of congress tourism. For example, the certified hotels in Zagreb have hosted the Olympic basketball team and handball team from Qatar, a football club from Saudi Arabia, a youth football team from Kuwait and several business delegations from the Middle East (Crnjak, 2014). One factor that has undoubtedly helped is also the direct air connection of Qatar Airways and the opening of the Qatari embassy in Zagreb, as well as business associations and investments in general (Šoštarić, 2014). According to PR data from the Hotel Esplanade, it is clear that since the introduction of halal standards, the hotel profit increased by $6 \%$ in 2013 , while the number of overnight stays increased by $4 \%$ (Grgić, 2014). ${ }^{6}$ Croats hope that by strengthening the halal supply they will manage to prolong the tourist season and to enhance the development of medical tourism, which is becoming increasingly interesting to the Arab markets (Pavičić, 2014; see also Ištaković, 2012).

\subsection{Halal concept in the Slovenian hotel industry}

In Slovenia, the concept of halal is still relatively undeveloped. In contrast to other EU countries, which have various halal butcher shops, restaurants, perfumeries, and personal hygiene products, the offer of halal products and services is predominantly poor in Slovenia. Apart from a

3 Caprice Hotel from Turkey, Al-Jawhara Hotel in Dubai, Hotel Sofyan Hotel and Hotel Tuara Natama in Indonesia, and DePalma Hotel in Malaysia were the first hotels to be transformed into halal hotels (Razalli et al., 2013).

4 Sixty per cent of the guests at Jawhara Hotels, an Arabic halal hotel chain, are non-Muslim, who appreciate its staff friendliness and family atmosphere (Alserhan, 2011); the biggest advantage of halal hotels is the spiritual experience (Rosenberg \& Choufany, 2009).

5 Under the auspices of the Ministry of Tourism and three other ministries, the centre organised the World Halal Day Croatia 2016 in November of that year (Croatian Chamber of Economy, 2016).

6 However, figures have to be understood in the context of public relations (PR), which is the usual technique of corporations. Apart from that, we have to take into consideration that so many other factors impact the hotels' performance (including profit). 
Table 1: Structure of the population and the sample according to the hotels' category

\begin{tabular}{|c|c|c|}
\hline \multirow{2}{*}{ Hotel category } & \multicolumn{2}{|c|}{ No. of hotels } \\
\cline { 2 - 3 } & Population & Sample \\
\hline $3^{*}$ & 175 & 14 \\
\hline $4^{*}$ & 122 & 19 \\
\hline $5^{*}$ & 9 & 1 \\
\hline
\end{tabular}

few manufacturers of food products that have been halal certified, and some trading companies, there are no other providers of these products and services (Kalčić, 2007, p.9; Pašić, 2009, p.49; Batagelj et al., 2014). In the hotel industry, the halal offer is also modest (see ' 1 Introduction'), and this area is not a theme of academic research. Accordingly, within the hotel industry it is necessary to start practically at the beginning, which means that it is necessary to first determine the knowledge of the hotel management about this topic and consequently identify the opportunities for progress that would be consistent with the identified trends at the global level; the main question is: to what extent are hotel managers familiar with the halal certification and on what basis would they decide on its implementation? Relying on existing studies is problematic, because they are rare (Samori \& Sabtu, 2012), characterised by political, economic and cultural differences: conducted on halal hotels in Muslim countries, e.g. Samori \& Sabtu (2012), Afifi (2014); focused on halal tourism in general, e.g. Al-Borzooei \& Asgari (2013), Hamameh \& Steiner (2004), Razzaq, Halla \& Prayag (2016), Battour, Ismail \& Battor (2010), Kovjanic, (2014), Battour \& Ismail (2016); focused on the global halal tourism market and its potentials (Crnjak, 2014; Saad, 2013; Kovjanic, 2014, p.36); focused on six dimensions of performance of the hotel (Razalli, Abdullah \& Yusoff, 2012) or focused on the (processing) industries, which are not directly related to tourism, e.g. Demirci, Soon \& Wallace (2016), Farouk, Pufpaff \& Amir (2016). Furthermore, we could not find any research that would highlight the views of managers regarding the halal offer in hotels (see "1 Introduction"). Consequently, based on the meta-analysis, this paper proposes the following claims:

- C1: Slovenian hotel managers are not familiar with the halal certificate.

- C2: Decision-making related to certification is at least two-dimensional.

\section{Methodology}

In the study, Slovenian hotels categorised with three stars or more, which are recorded in the register of the Slovenian accommodation providers (www.slovenia.info/register$\underline{\mathrm{NO}}$ ) were considered. Hotels with gaming activities were discarded, because these kinds of services are incompatible with Islamic principles. After this selection process, the population was obtained, summarised in Table 1. By applying the method of random sampling, 100 hotels were selected, and a questionnaire was sent by e-mail to the hotel managers (respondents). In total, 34 completed surveys were obtained, which represents $11 \%$ of the population. The size (in relation to the category) of this sample was problematic for further analysis; consequently, some adjustments (weighting) to correct for under-representation of certain characteristics were implemented. ${ }^{7}$

We relied on the assumption that for the research it is particularly important to obtain information from the part of the researched population with representative members of a target group (Altinay \& Paraskevas, 2008). Therefore, we accept the fact that we operate with a small and then weighted sample, which can additionally be defined by the following characteristics:

the shortest operating period of a hotel is 2 years, while the longest operating period is 101 years. On average, hotels had been operating for 21.87 years;

the hotel with the lowest number of employees has 4 employees, while the largest has 200 employees. The average number of employees per hotel in the sample is 26 ;

$74.2 \%$ of hotels are independent organisations with one hotel.

The development of the questionnaire was a more complex process, since it was done on the basis of the objectives of the research for reasons mentioned at the end of the previous chapter (' 3 Halal (tourism) and hotels'). A preliminary web questionnaire pertaining to managers' perceptions was initially developed from the relevant research, i.e. Rosenberg \& Choufany (2009), Henderson (2010), Razzalli, Abdullah \& Yusoff (2012), which were focused on different perspectives of halal context. The questionnaire has been based on the Technological Acceptance Model (TAM), developed by Davis (1989), which represents an extension of the theory of rational action

7 This intervention impacted all further calculations. 
(Theory of Reasoned Action (TRA)) (Fishbein \& Ajzen (1975); Ajzen \& Fishbein (1980)). The final version of the questionnaire, which was the result of interviews with three experienced researchers, included 11 questions with dichotomous or ordinal variables, with the level of agreement on a scale of 1 to 5 , where 1 marked the lowest level of agreement, 5 the highest. The following ordinal variables (claims/questions) were included in the questionnaire:

- Q1 How well do you know the halal certificate for hotels, which includes hotel standards adapted to the needs of Muslim guests?

- Q2 The decision on obtaining the halal certification depends on the amount of information about its positive impact on the hotel performance;

- Q3 The possibility for adapting the existing hotel services and facilities to standards required by the halal certificate;

- Q4 The decision to obtain the halal certificate depends on the simplicity and effectiveness of the procedure for obtaining the halal certificate;

- Q5 The decision to obtain the halal certificate depends on the amount of financial investment required for obtaining the halal certificate;

- Q6 The decision to obtain the halal certificate depends on the increase in the number of Muslim guests;

- Q7 The decision to obtain the halal certificate depends on the decisions of other Slovenian hotels about certification.

The survey was conducted in the winter of 2015. The acquired data were then statistically analysed using the SPSS 20.0 statistical software package, with which the calculations were made using the descriptive analysis, principal component analysis (PCA) and analysis of the factor loadings. A 0.05 significance level was chosen before the data analyses.

\section{Results}

At the beginning of the empirical analysis, some basic calculations were carried out, which served to verify the data obtained, which is particularly important because of the way the research instrument was developed. First, the relatively low average values $(\mathrm{x})$ characterise the variables from Q1 to Q7 (see Table 2). However, the high Cronbach $\alpha(0.890)$ indicates a high reliability of the construct.

Second, the Spearman correlation test was employed to verify the correlation between all included variables that influence the decisions of hoteliers for a halal certificate and the category of the hotel. The decision related to possibilities to adjust the services and facilities to the requirements of the halal certification (Q3), the decision to obtain the halal certification if the latter would not require significant financial investments (Q5) and the decision to obtain the halal certification if this would increase the number of Muslim guests (Q6) show values $0.387 \leq \rho \geq 0.653,{ }^{8}$ which indicates a significant correlation between these variables and the hotel category; four-star hotels reach the highest average ratings. Lower positive correlation is evident with the decision that depends on the amount of information about its positive impact on the hotel performance (Q2) $-\rho=0.168$. The same calculation was made for the connection between the same ordinal variables and the dichotomous variable hotel is part of a hotel group, for which all the coefficients were in the interval $-0.331 \leq \rho$ $\geq-0.168$. This suggests that the decision on the halal offer is not linked to the internal structure (organisation) of the hotel organisation.

Third, results in Table 2 reflect the fact that Slovenian hoteliers (managers) have not (yet) developed a positive opinion on the halal certificate. This is also supported by the high coefficient of variation, which is indicated by the spread of answers. In addition, with the descriptive analysis of the two additional variables, we have found that more than half of the respondents are familiar with the concept of halal tourism (52.6\%), but the proportion of

Table 2: Descriptive statistics (Source: authors)

* weighted sample

\begin{tabular}{|c|c|c|c|c|c|c|c|}
\hline Variable & $\mathrm{n1}^{*}$ & Minimum & Maximum & $\overline{\mathrm{x}}$ & $\Sigma$ & $\gamma_{1}$ & $\beta_{2}$ \\
\hline Q1 & 306 & 1 & 5 & 1.58 & 0.936 & 1.852 & 4.147 \\
\hline Q2 & 306 & 1 & 5 & 2.50 & 0.844 & 0.961 & 0.438 \\
\hline Q3 & 306 & 1 & 5 & 2.55 & 0.913 & 0.858 & 1.222 \\
\hline Q4 & 306 & 1 & 5 & 2.71 & 1.002 & 0.869 & 0.088 \\
\hline Q5 & 306 & 2 & 5 & 2.83 & 0.925 & 0.819 & -0.342 \\
\hline Q6 & 306 & 2 & 5 & 3.10 & 1.021 & 0.514 & -0.885 \\
\hline Q7 & 306 & 1 & 5 & 2.48 & 0.843 & 0.820 & 0.525 \\
\hline
\end{tabular}

8 Correlation is significant at the 0.01 level (2-tailed). 
those who have not even thought about obtaining the halal certification for their hotel is dominant (73.1\%). ${ }^{9}$ Consequently, $\mathrm{C} 1$ was confirmed. It is necessary to point out that the highest $\bar{x}$ present variables for which the decision to obtain the halal certificate depends on the increase in the number of Muslim guests (Q6) and decisions to obtain the halal certificate would not require major financial investments (Q5).

Our intention was also to define the managers' decision to obtain the halal certification as a new construct. Therefore, we used a multivariate PCA method. In this way, we gained new information on the structure of the variables and created new factor(s). Initially, variables Q1 and Q3 were excluded from the analysis (does not relate completely to the managers' decision-making). We wanted to make sure that the correlation between variables is large enough to allow us to replace the basic variables with the principal components. The high value of the KMO coefficient (0.801) and the significant Bartlett's test of sphericity $\left(\chi^{2}=952.436, \mathrm{df} .=10 ; \mathrm{p}<0.000\right)$ allowed us to continue with the multivariate analysis. To determine the main factors affecting the decision on obtaining the halal certification, we employed the analysis of the factor loadings. The results show how the highest factor determines the most important factor affecting the decision to accept the halal certificate, which is the simplicity and efficiency of the procedure itself (Q4) (see Table 3). In the second place is the fact that the process does not require a major financial investment (Q5), and least influential is the information on the positive impact on hotel performance (Q2). Next, we used PCA method to reduce the dependent variables to a smaller number of factors. One factor with eigenvalues greater than 1.00 that explained $66.20 \%$ of the total variance was identified (see Figure 1). This suggests that the scale items are uni-dimensional. The identified factor can logically be called decision making. Consequently, C2 was rejected.

Table 3: Analysis of the factor loadings of the main components (Source: authors)

\begin{tabular}{|c|c|c|c|}
\hline \multicolumn{2}{|c|}{ Component 1 } & $\overline{\mathrm{x}}$ & $\Sigma$ \\
\hline Q4 & 0.934 & 2.71 & 1.002 \\
\hline Q5 & 0.892 & 2.83 & 0.925 \\
\hline Q6 & 0.817 & 3.10 & 1.021 \\
\hline Q7 & 0.731 & 2.48 & 0.843 \\
\hline Q2 & 0.664 & 2.50 & 0.844 \\
\hline
\end{tabular}

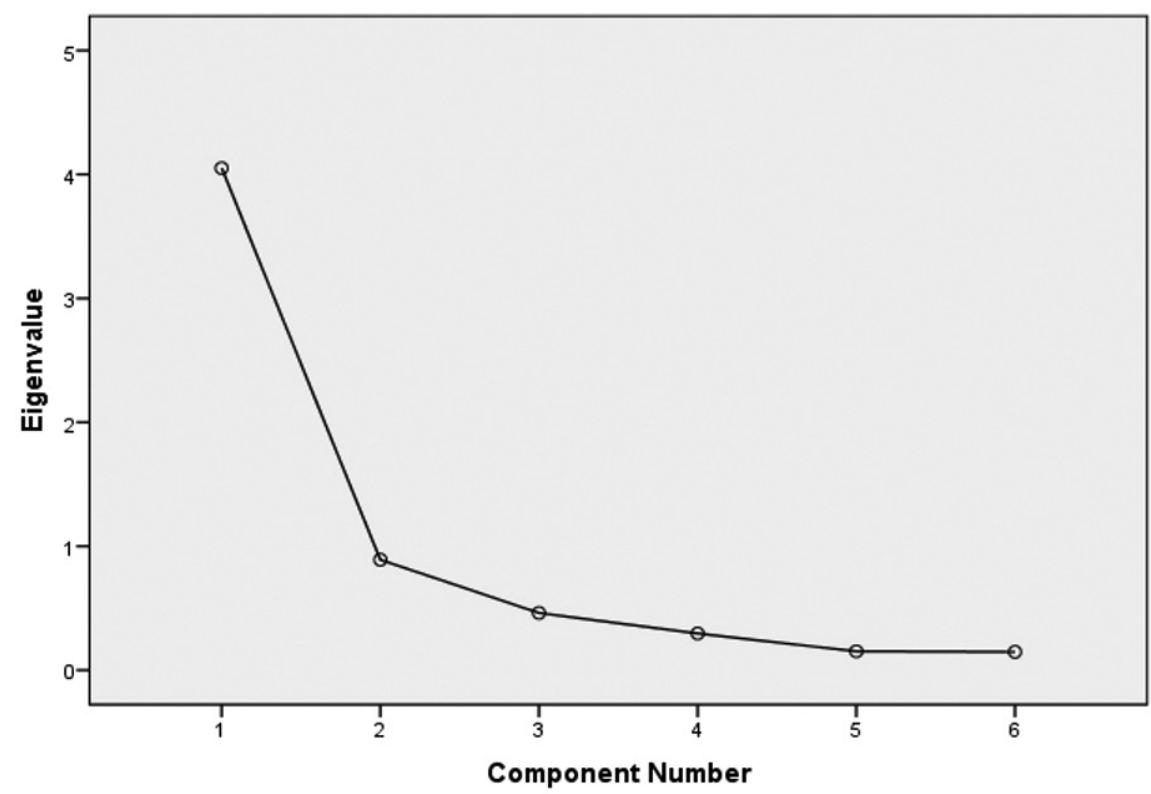

Figure 1: The component's eigenvalues (Source: authors)

$9 \quad$ Both variables are dichotomous. 


\section{Discussion and conclusion}

The main contribution of this study is to deepen the perspective of the development of tourism in an area that remains a relatively undeveloped and unknown niche within Slovenian tourism, yet very promising in the global context. Based on this assumption, Slovenia could increase the visits of Muslim tourists by incorporating halal content in its tourism services and facilities, since it already offers many features that appeal to the Muslim guest, e.g. culture, history and art, wellness. According to the (research) claims, we established that Slovenian hotel managers are not familiar with the halal certification and, therefore, are not taking it into consideration; their decision-making process for adopting the halal certificate would be determined by the simplicity and efficiency of the procedure itself and on the fact that the procedure does not require a major financial investment. The certification procedure remains quite unclear and inconsistent. This is problematic: Islamic communities are tied to each country, and the interpretation of certain religious aspects may also differ between them; a unified mechanism for certification on the international, European or global, level has not been yet established (Rosenberg \& Choufany, 2009; see also Crnjak, 2014; Obućina, 2014). Institutionalised practices for the certification of halal hotels as well as institutions that would define uniform criteria about the conditions for obtaining a halal certificate does not yet exist on the market (Henderson, 2010). Hence, findings on the efficiency of the procedure itself and on financial investment are basically consistent with the allegations of Razzalli, Abdullah and Yusoff (2012) on the dimensions of the hotel performance, which includes the effectiveness and economic prudence. Due to the significant cultural/religious differences, halal adjustments may affect certain hotel services, hotels interiors, and other features (according to the characteristics of halal hotels indicated by Henderson, 2010); they are justified only when they have a significant (positive) impact on sales. Therefore, their implementations require additional caution in the decision-making process of hotel managers in Slovenia, where the Islamic religion is not dominant; managers' practical orientation and pragmatism are reflected in the decision-making process that would be influenced by the possibilities to adapt the existing hotel facilities and services to the standards determined by the halal certificate. The process of the adaptation of existing facilities and services should be supported by external partners, which could lead to the development of higher quality and more innovative products. Exactly this approach has been detected as a weak point of the Slovenian tourism (see Uran Maravić, Križaj \& Lesjak (2015)).

The hotel industry recognises that an increased demand for certifications requires a consensus on uniform guidelines and standardised procedures to protect and ensure a consistent quality of halal products and services (Halim $\&$ Salleh, 2012). Therefore, the EU has already begun the process to standardise the procedures for the certification and thus facilitate a transparent functioning of the necessary mechanisms (Obućina, 2014). The problematic aspect of the topic has also been shown by the results of our study, in which we found that hoteliers' decisions for adopting the halal certificate largely depend on the perception of the complexity and costs of the certification process. The interest of Slovenian hotel managers for a halal certificate could be increased by developing clear and simple procedures for obtaining the halal certification, which would favourably affect the perception of the degree of difficulty and the possibility to adjust to the standards of halal certificates. This would help hoteliers make decisions that would be in line with the global trends (see Dinar Standard (2012), Baker (2011) and Razzali, Yusoff \& Roslan (2013)) and competitors in the neighbourhood (see Crnjak (2014), Šoštarić (2014), Latinović (2016)).

In order to improve the perception and understanding of the complexity of the process for obtaining the halal certificate, an interdisciplinary team consisting of (a) organisers or experts for standardisation, (b) experts of hospitality/hotel industry, (c) experts of halal standards and (d) religion/culture of Islam from Slovenia and/or abroad should define/develop: (a) clear halal standards for the hotel industry (in formal written form) and, on this basis, (b) special educational/training programs, including all the necessary consultations, (c) publicly available material (standards) and other quick information, e.g. via web page. In addition to these recommendations, it is necessary to strengthen the research of halal tourism in Slovenia, since this would help to overcome stereotypes and strengthen the awareness of hotel managers and other relevant stakeholders in tourism about the potentials/opportunities, to connect the specific business concept with the specific sectarian organisational culture ${ }^{10}$ and provide a level of quality that is consistent with the expectations of the guests (see Parasuraman, Zeithaml \& Berry (1985) or Kukanja, Gomezelj Omerzel \& Kodrič (2016)). In this sense, this research could help develop national halal systems in Slovenia and in the wider region as well as improve the perception of hotel managers and facilitating an easier integration of services adjusted to the needs of Muslims (as well as other guests) in the hotel facilities and services; the perspective of corporate social responsibility (CSR) in the hospitality industry should not be neglected (see Kukanja, Planinc \& Šuligoj (2016) or Štrukelj \& Šuligoj (2014)).

This survey, like any scientific study, has certain restrictions. The constraints of the quantitative research include low response rates of hotel managers and a general lack of knowledge about halal services among Slovenian hotel managers. To ensure the representativeness of the results, weighting of the sample was required. Nevertheless,

10 In general presented by Šuligoj \& Mrđa (2016). 
our study can be seen as a relevant (first) study on the specific form of the tourism/hotel industry. Another limitation is also represented by the use of an online questionnaire, which excludes the role of the interviewer and thus the possibility of the immediate elimination of possible confusions and mistakes in completing the surveys. An interesting example is variable Q3, which was not clearly linked to the decision making and consequently excluded from the calculations related to $\mathrm{C} 2$. As a general restriction, we can mention the absence of related research on halal tourism, which could be effectively used for the development of the instrument and for argumentation and interpretation of the final findings. Despite these limitations, with the use of selected methodology, the goals of the study have been successfully achieved.

\section{References}

Afifi, F. M. (2014). How do Egyptian hotel management students feel about studying alcohol service? Journal of Hospitality, Leisure, Sport \& Tourism Education, 14 (April 2014), 15-25, http://dx.doi.org/10.1016/j. jhlste.2013.12.004

Ajzen, I. \& Fishbein, M. (1980). Understanding Attitudes and Predicting Social Behavior. Englewood Cliffs: Prentice-Hall.

Aladjem, S. (2012). Welcoming Muslim Tourists to Christian Cultures. Retrieved April 12, 2015, from http:// ecologybg.com/naruchnikENG.pdf

Al Bawaba (2007). Almulla launches world's first Sharia compliant hotel brand portfolio. Retrieved May 12, 2015, from nhttp://www.albawaba.com/news/almulla-launches-world's-first-international-sharia-compliant-hotel-chai

Al-Hamameh, A. \& Steiner, C. (2004). Islamic tourism: rethinking the strategies of tourism development in the Arab world after September 11, 2001, Comparitive Studies of South Asia, Africa and the Middle East, 24 (1), 18-27, http://dx.doi.org/10.1215/1089201X-24-1-175

Alserhan, B. A. (2011). The principles of Islamic Marketing. Surrey: Gower Publishing Ltd.

Altinay, L. \& Paraskevas, A. (2008). Planning Research in Hospitality and Tourism. New York: Butterworth-Heinemann.

Baker, A. (2011). The Principles of Islamic Marketing., Surrey: Gower Publishing Ltd.

Batagelj, B., Bezgovšek, V., Mlakar, S., Povše, V., Šebrek, L., Zupančič, J. \& Vulič, G. (2014). Hrana halal v Sloveniji [Halal food in Slovenia]. In Trendi in izzivi $v$ živilstvu, prehrani, gostinstvu in turizmu, Zbornik prispevkov 3. mednarodne strokovne konference, 24. 25. oktober 2014 [Trends and challenges in food technology, nutrition, hospitality and tourism, Conference proceedings of the 3rd International Professional Conference, October $24^{\text {th }}-25^{\text {th }} 2014$, Ljubljana, Slove- nia] (134 - 140). Ljubljana: Biotehniški izobraževalni center, Ljubljana.

Battour, M., Ismail, M. N. \& Battor, M. (2010). Toward a halal tourism market. Tourism Analysis, 15 (4), 461-470, http://dx.doi.org/10.3727/10835421 0X12864727453304

Battour, M., Ismail, M. N. \& Battor, M. (2011). The impact of destination attributes on Muslim tourist's choice. International Journal of Tourism Research. 13 (6), $527-$ 540, http://dx.doi.org/10.1002/jtr.824

Battour, M. \& Ismail, M. N. (2016). Halal tourism: Concepts, practises, challenges and future. Tourism Management Perspectives. 19 (July 2016), 150-154, http:// dx.doi.org/10.1016/j.tmp.2015.12.012

Boisard, M. A. (2002) Humanizam islama [humanization of islam]. Sarajevo: El-Kalem.

Borzooei, M. \& Asgari, M. (2013). The Halal brand personality and its effect on purchase intention. Interdisciplinary Journal of Contemporary Research in Business, 5 (3), 481-492.

Crnjak, M. (8 september 2014). Halal turizam: S trpeze teške 140 mlrd. dolara Hrvatska ubire mrvice [Halal tourism: From the table weighing 140 billion dollars, Croatia collects only crumbs]. Poslovni dnevnik. Retrieved December 16, 2014, from http://www.poslovni. $\mathrm{hr} / \mathrm{mobile} / \mathrm{hrvatska} / \mathrm{halal}$-turizam-s-trpeze-teske-140mlrd-dolara-hrvatska-ubire-mrvice-278777

Croatian Chamber of Economy (2016). World Halal Day Croatia 2016. Retrieved Jun 1, 2016, from http:// www.hgk.hr/sektor-centar/sektor-turizam/world-halal-day-croatia-2016

Davis, F. D., Bagozzi, R. P. \& Warshaw, P. R. (1989). User Acceptance of Computer Technology: A Comparison of Two Theoretical Models. Management Science, 35 (8), 982-1003, http://dx.doi.org/10.1287/ mnsc.35.8.982

Demirci, M. N., Soon, J. M. \& Wallace, C. A. (2016). Positioning food safety in Halal assurance. Food Control, 70 (December 2016), 257-270, http://dx.doi. org/10.1016/j.foodcont.2016.05.059

Din, K. H. (1989) Islam and tourism: patterns, issues and options. Annals of Tourism Research, 16 (4), 542-563, http://dx.doi.org/10.1016/0160-7383(89)90008-X

Dinar Standard. (2012) Global Muslim Lifestyle Travel Market 2012: Landscape \& Consumer Needs. Retrieved December 24, 2013, from http://static.hosteltur.com/web/uploads/2013/10/turismo_islyAmico_informe_2012_2.pdf

Duman, T. (2011) Value of Islamic Tourism Offering: Perspectives from the Turkish Experience. Islam and Civilisational Renewal (ICR), 3 (4), 718-739. Retrieved December 12, 2015, from http://www.icrjournal.org/ icr/index.php/icr/article/view/13

FAO (n.d.). General guidelines for use of the term "halal", CAC/GL 24-1997. Retrieved May 2, 2016, from http:// 
www.fao.org/docrep/005/Y2770e/y2770e08.htm

Farouk, M. M., Pufpaff, K. M. \& Amir, M. (2016). Industrial halal meat production and animal welfare: A review. Meat Science, 120 (October, 2016), 60-70, http:// dx.doi.org/10.1016/j.meatsci.2016.04.023

Fishbein, M. and Ajzen, I. (1975). Belief, Attitude, Intention, and Behavior. Reading: Addison-Wesley.

Grgić, I. (15 September 2014). Halal tržište izazov za Hrvatske tvrtke: pozicioniranje na najperspektivnijem brzorastućem tržištu [Halal market as a challenge for Croatian companies: positioning on the most promising fast-growing market]. Privredni vijesnik. 20-21.

Halim, M. A. A. \& Salleh, M. M. M. (2012). The possibility of uniformity on halal standards in organization of Islamic countries (OIC) country. World Applied Sciences Journal, 17 (17), 6-10.

Hashim, N. H., Murphy, J. I. \& Muhamad, N. (2007). Islam and online imagery on Malaysian tourist destination websites. Journal of Computer-Mediated Communication, 12 (3), 1082-1102, http://dx.doi.org/10.1111/ j.1083-6101.2007.00364.x

Henderson, J. C. (2003). Managing tourism and Islam in Peninsular Malaysia. Tourism Management, 24 (4), 447-456, http://dx.doi.org/10.1016/S0261$5177(02) 00106-1$

Henderson, J. C. (2010). Sharia-compliant Hotel. Tourism and Hospitality Research. 10 (3), 246-254, http://dx. doi.org/10.1057/thr.2010.3

Ištaković, A. (2012) Hrvatska u multikulturalnom svijetu. Media, culture and public relations, 3 (2), 150-157.

Jašić, M., Bašić, M., Sakić, A. \& Čengić, F. (2007), Halal status aditiva u mlijeku i mliječnim proizvodima [The halal status of additives in milk and dairy products], Mljekarstvo: časopis za unaprjeđenje proizvodnje $i$ prerade mlijeka, 57 (2), 153-159.

Kalčić, Š (2007). Slovenski muslimani: kdo so, organiziranost in državnopravno normiranje $\mathrm{v}$ antropološki presoji [Slovenian Muslims: who they are, organisation and national-legal standardisation through anthropological evaluation]. Dve domovini- Two Homelands, Vol. 26 (2007), pp. 7-29.

Kovjanic, G. (2014). Islamic Tourism as a Factor of the Middle East Regional Development. Turizam. 18, 3343.

Kukanja, M., Gomezelj Omerzel, D. \& Kodrič, B. (2016). Ensuring restaurant quality and guests' loyalty: an integrative model based on marketing (7P) approach. Total Quality Management \& Business Excellence, 1-17, http://dx.doi.org/10.1080/14783363.2016.1150172

Kukanja, M., Planinc, T., Šuligoj, M. (2016). Influence of managers' demographic characteristics on csr practices in the restaurant industry: the case of Slovenia. Tourism and Hospitality Management. 22 (2), 151-172, http://dx.doi.org/10.20867/thm.22.2.2

Latinović, V. (5 May 2016). Halal turizam - izvrsna je prilika za Hrvatsku [Halal tourism - an excellent opportunity for Croatia]. Glas Slavonije. Retrieved May 20, 2016, from http://www.glas-slavonije.hr/301305/7/ Halal-turizam---izvrsna-je-prilika-za--Hrvatsku.

Morgan, N., Pritchard, A. \& Piggott, R. (2002). New Zealand, $100 \%$ pure. The creation of a powerful niche destination brand. The Journal of Brand Management, 9 (4), 335-354, http://dx.doi.org/10.1057/palgrave. bm. 2540082

Nasr, S. H. (2007). Islam: religija, zgodovina in civilizacija [Islam: religion, history and civilization]. Maribor: Litera.

Obućina, V. (2014). Catering to Muslims, Croatia becomes "halal friendly « country. Retrieved December 16, 2014, from http://halal.hr/nova/catering-to-muslims-croatia-becomes-,,halal-friendly"-country/

Onislam.net (2010), Blooming Halal Travel. Retrieved October 13, 2012, from Http://www.onislam.net/english/news/global/448922-blooming-halal-travel-.html

Parasuraman, A., Zeithaml, V. A., \& Berry, L. L. (1985). A conceptual model of service quality and its implications for future research. Journal of Marketing, 49 (4), 41-50, http://dx.doi.org/10.2307/1251430

Pašić, A. (2009). Perspektive in dileme muslimanskih skupnosti [Perspectives and dilemmas of Muslim communities]. Monitor ISH, 11 (2), 37-54.

Pavičić, D. (23 jun 2014). Halal turisti sve poželjniji troše 500 dolara više od prosjeka EU [Halal tourists more preferable - spend 500 US dollars more than the EU average]. Večernji list. Retrieved May 20, 2016, from: http://www.vecernji.hr/turisticka-patrola/halalturisti-sve-pozeljniji-trose-500-dolara-vise-od-prosjeka-eu-946277

Piangpis, S., Oraphan, C. \& Hamzah, A. R. (2014). Understanding Behavior and Needs of Halal in Andaman Gulf of Thailand: A Case of Asian Muslim. Journal of Advanced Management Science, 2 (3), 216-219, http:// dx.doi.org/10.12720/joams.2.3.216-219

Rajagopal, S., Ramanan, S., Visvanathan R. \& Satapathy, S. (2011). Halal certification: implication for marketers in UAE. Journal of Islamic Marketing, 2 (2), 138-153, http://dx.doi.org/10.1108/17590831111139857

Razalli, M. R., Abdullah, S. \& Yusoff, R. Z. (2012). Is Halal certification process "green"?, The Asian Journal of Technology Management, 5 (1), 23-30.

Razalli, M. R., Yusoff R. Z. \& Roslan, M. W. M. (2013). A Framework of Halal Certification Practices for Hotel Industry. Asian Social Science, 9 (11), 316-326, http:// dx.doi.org/10.5539/ass.v9n11P316

Razzaq, S., Halla, C. M., \& Prayag, G. (2016). The capacity of New Zealand to accommodate the halal tourism market - or not. Tourism Management Perspectives, 18, (April 2016), 92-97, http://dx.doi.org/10.1016/j. tmp.2016.01.008

Rosenberg, P. \& Choufany, H. M. (2009), Spiritual lodg- 
ing - the sharia-compliant hotel concept, HVS. Dubai: Global Hospitality Service.

Saad, K. (2013). Halal Tourism: Way to Muslim-friendly Environment. An Industry that Goes Mainstream. Retrieved April 16, 2014, from http://www.onislam.net/ english/culture-and-entertainment/travels-a-adventures/455441-halal-tourism-way-to-muslim-friendly-environment-.html?Adventures $=$

Samori, Z. \& Sabtub, N. (2012). Developing Halal Standard for Malaysian Hotel Industry: An Exploratory Study. Procedia - Social and Behavioral Sciences, 121 (March 2014), 144-157, http://dx.doi.org/10.1016/j.sbspro.2014.01.1116

Slovenian tourist board (2017). Turizem v številkah 2016. Ljubljana: Slovenian tourist board.

Slovenian tourist board (n.d.). Slovenski turizem v 25 letih. Retrieved October 1, 2017, from https://www.slovenia. info/sl/poslovne-strani/o-sto/25-let-turizma.

Sureerat, C., Oraphan, C., Jirapa, C., Pingpis, S. \& Sudarat, N. (2015). Increasing Halal Tourism Potential at Andaman Gulf in Thailand for Muslim Country. Journal of Economics, Business and Management, 3 (7), 739-741, http://dx.doi.org/10.7763/JOEBM.2015. V3.277

Šoštarić, T. (6. julij 2014). Hrvatska - poželjna 'halal friendly' destinacija [Croatia - desirable 'halal friendly' destination]. Aljazeera. Retrieved May 20, 2016, from http://balkans.aljazeera.net/vijesti/hrvatska-pozeljna-halal-friendly-destinacija

Štrukelj T. \& Šuligoj M. (2014) Holism and social responsibility for tourism enterprise governance. Kybernetes, 43 (3/4), 394-412, http://dx.doi. org/10.1108/K-07-2013-0159

Šuligoj, M. \& Mrđa, I. (2016). Percepcije organizacijske kulture turistične destinacije: primer severnojadranske obalne destinacije [Perceptions of the organisational culture of a tourist destination: the case of a North Adriatic coastal destination]. Teorija in praksa, 53 (2), 366 - 387.

Timothy, D. J. \& Olsen, D. H. (2006). Tourism, Religion and Spiritual Journeys. Oxford: Routledge.

The Government of the Republic of Slovenia (2012). The 2012-2016 Slovenian tourism development strategy. Retrieved March 1, 2016, from http://www.mgrt.gov. si/fileadmin/mgrt.gov.si/pageuploads/turizem/Turizem-strategije_politike/Strategija turizem spreje- to 7.6.2012.pdf

The Government of the Republic of Slovenia (2012). The 2017-2021 Strategy for the Sustainable Growth of Slovenian Tourism. Retrieved October 12, 2017, from http://www.mgrt.gov.si/fileadmin/mgrt.gov.si/pageuploads/Strategija_turizem koncno_9.10.2017.pdf

Uran Maravić, M., Križaj, D. \& Lesjak, M. (2015). Innovation in Slovenian tourism organisations. Tourism and hospitality management, 21 (1), 51-62.

Zaliani, S., Omar, A. \& Kopong, S. (2011). An explanatory study on the factors influencing the non-compliance to Halal among hoteliers in Malaysia. International Business Management, 5 (1), 1-12, http://dx.doi. org/10.1016/j.sbspro.2014.01.1116

Zulkifli, W.S.W., S.A. Rahman, S., Awang, K. W. \& Che Man, Y. (2011). Developing the framework for Halal friendly tourism in Malaysia. International Business Management, 5 (6), 295-302, http://dx.doi. org/10.3923/ibm.2011.295.302

Metod Suligoj, PhD, is an Associated Professor at the Faculty of Tourism Studies - Turistica, University of Primorska, Slovenia. His main research interests include quality in hospitality industry, management in hotel industry, human resources in tourism and special interests tourism. He started his professional career in the hotel industry, where he was promoted to Hotel Manager and later to Project Manager. In addition to research and teaching activities, he is also an Accommodation Assessor, an EFQM Excellence Assessor in Slovenia and an Experts witness in the fields of quality in tourism and in the hospitality industry. Moreover, he works as a Reviewer for various international scientific journals.

Helena Maruško graduated in Cultural studies at the Faculty of Social Sciences (University of Ljubljana) in 2004. She developed her professional career by working for global international companies like Ebay in Dublin (Ireland) and Webcertain in York (Great Britain). In 2015 she received her master's degree in Tourism at the Faculty for Tourism Studies - Turistica, Portorož, University of Primorska. She participated in the development of the Ljubljana's cultural development strategy and the development of the Tourism strategy of Velenje. Currently she works for an independent company in the field of tourism and marketing. 